\title{
Mechanical Assessment of SS316 using Single Pass Tig Welding Process
}

\author{
K.L.N.Murthy \\ Asst.Professor, Mechanical Department, \\ Sreyas Institute of Technology, Tattannaram, India \\ B.Sandeep \\ Asst. professor, Mechanical Department, \\ Sreyas Institute of Technology, Tattannaram, India \\ T.Krishna Chaitanya \\ Asst. professor, Mechanical Department, \\ Sreyas Institute of Technology, Tattannaram, India
}

\begin{abstract}
Welding is the process of joining two similar or dissimilar metal pieces permanently by the application of heat. Inspite of a number of types of welding processes, Tig (Tungsten Inert Gas) welding has been widely used in the industries because of its ease in usage and also it shields the fusion zone from the atmospheric contaminants during welding and helps in improving the strength of the weld bead. The present work aims at joining of two similar metal pieces of AISI SS316 of 100x20x5mm each using TIG welding. Experimentations were carried using Vickers hardness testing machine, universal testing machine for finding tensile strength, microstructures of all the specimens at fusion zone and $\mathrm{HAZ}$ were found under 200x of magnification. An orthogonal array L2 is formed to find out the maximum tensile stress, hardness of the weldment at a load of $600 \mathrm{KN}$.
\end{abstract}

Keywords- similar materials, tensile strength, orthogonal array, hardness

\section{INTRODUCTION}

HAZ, fusion zone, base metal are the three important zones of a welding. Failure of any welding occurs due to improper transfer of heat from the fusion zone to the parent material, wrong selection of the welding process parameters and the welding process. Among the anourmos number of welding processes available in practice, Tig welding is one of the industrially proven permanent joining process of various metals because of its shielding action by the inert gas (helium or argon) towards the fusion zone and heat affected zone.

\section{MATERIAL}

Stainless steel is a form of alloy steel that contains $12 \%$ or more chromium percent in order to protect from rust, corrosion during its usage in various applications. Based on the crystalline structure, SS is available in three different forms
1. Austenitic steel(FCC)
2. Martensitic steel(BCC)
3. Ferritic steel(BCC)

Various grades of stainless steels are classified under these different crystal structures and each grade of steel contains various chromium and nickel percentages. Grade 200,300 falls under austenitic steels and SS304 is also referred as $18 / 8(18 \%$ chromium, $8 \%$ nickel)steel which is the most widely used steel and next to it is SS316 which is available with the composition of 18/10.eventhough SS316 falls second in place but because of the presence of the 
molybdenum(2-3\%) in it, the material has good corrosion resistance properties and can be used in the coastal area plant which is not possible by SS304.

\section{EXPERIMENTATION}

SS316 plate of $5 \mathrm{~mm}$ thickness is chosen as work piece material. V-groove butt weld joint is made with these $5 \mathrm{~mm}$ thick SS plates by maintaining parameter values as mentioned in table. The work material dimensions are considered as $120 \mathrm{X} 50 \mathrm{X} 5 \mathrm{~mm}$. Experimental trails are carried out randomly to minimize the effect of noise factors. For each of the v-groove butt welded joint made the responses are the bead widths, bead height, heat input, and area of penetration.

The parameters which are required for the experimentation are arranged by means of Taguchi's table and Taguchi's $\mathrm{L}_{2}$ orthogonal array is constructed. Two levels and two different parameters are formed in the tabular column. The filler material used during welding is SS316 same as the parent material. Table 1 shows the mechanical properties of SS316 material and table two shows the tensile test results of all the specimens.

MECHANICAL PROPERTIES OF SS316

\begin{tabular}{|c|c|c|c|c|c|}
\hline $\begin{array}{l}\text { Tensile } \\
\text { strength } \\
\text { (Mpa) }\end{array}$ & $\begin{array}{c}\text { Yield } \\
\text { strength(Mpa) }\end{array}$ & $\begin{array}{l}\text { Density } \\
\mathrm{kg} / \mathrm{m}^{3}\end{array}$ & $\begin{array}{c}\text { Melting } \\
\text { point } \\
{ }^{\mathrm{O}} \mathrm{C}\end{array}$ & $\begin{array}{c}\text { Thermal conductivity } \\
\text { w/m.k }\end{array}$ & \% Elongation \\
\hline 515 & 205 & 8000 & $1400-1450$ & 21.5 at $500{ }^{\circ} \mathrm{C}$ & 20 \\
\hline
\end{tabular}

Tab 1. $\mathrm{L}_{2}$ orthogonal array

\begin{tabular}{|c|c|c|}
\hline Trail no & Current(amps) & Rrot gap (mm) \\
\hline 1 & 80 & 1 \\
\hline 2 & 80 & 1.5 \\
\hline 3 & 90 & 1 \\
\hline 4 & 90 & 1.5 \\
\hline
\end{tabular}

Tab. 2 


\begin{tabular}{|c|c|c|c|c|c|}
\hline $\begin{array}{c}\text { Sample } \\
\text { no. }\end{array}$ & $\begin{array}{l}\text { Current } \\
\text { (Amps) }\end{array}$ & $\begin{array}{l}\text { Root } \\
\text { gap } \\
(\mathrm{mm})\end{array}$ & $\begin{array}{c}\text { Tensile } \\
\text { strength } \\
\left(\mathrm{N} / \mathrm{mm}^{2}\right) \\
\text { (minimum) }\end{array}$ & $\begin{array}{c}\text { Tensile } \\
\text { strength } \\
\left(\mathrm{N} / \mathrm{mm}^{2}\right) \\
\text { (maximum) }\end{array}$ & $\begin{array}{l}\text { Tensile strength } \\
\left(\mathrm{N} / \mathrm{mm}^{2}\right) \\
\text { (experimental) }\end{array}$ \\
\hline 1 & 80 & 1 & 280 & 515 & 337.849 \\
\hline 2 & 80 & 1.5 & 280 & 515 & 396.985 \\
\hline 3 & 90 & 1.5 & 280 & 515 & 397.777 \\
\hline 4 & 90 & 1 & 280 & 515 & 459.159 \\
\hline
\end{tabular}

Tab.3

The above table clearly shows that the maximum tensile stress is obtained at sample 4 and lowest tensile stress is obtained at sample 1.The highest tensile stress found at sample 4 is due to the high current and less root gap but still the value falls below the maximum tensile stress value of ss 316 which is considered to $515 \mathrm{~N} / \mathrm{mm} 2$.

\section{RESULTS AND DISCUSSIONS}

Two metal pieces were machined together form an angle of $60^{\circ}$ between them $30^{\circ}$ each, then a but joint is formed using Tig welding. The Parameters selected are shown $\mathrm{n}$ the tabular column. First tensile test is performed with the selected parameters.

\begin{tabular}{|c|c|c|c|c|}
\hline Parameter & Notation & Units & \multicolumn{2}{|c|}{ Level of current } \\
\hline Welding current & & & $\mathrm{L}_{1}$ & $\mathrm{~L}_{2}$ \\
\cline { 3 - 5 } & & & 80 & 90 \\
\hline Root gap & $\mathrm{I}$ & Amp & & \\
\hline
\end{tabular}

Tab. 4

The above table clearly shows that the maximum tensile stress is obtained at sample 4 and lowest tensile stress is obtained at sample 1.The highest tensile stress found at sample 4 is due to the high current and less root gap but still the value falls below the maximum tensile stress value of ss 316 which is considered to $515 \mathrm{~N} / \mathrm{mm} 2$.

\section{GRAPHS AND TEST RESULTS FOR INDIVIDUAL SPECIMEN}

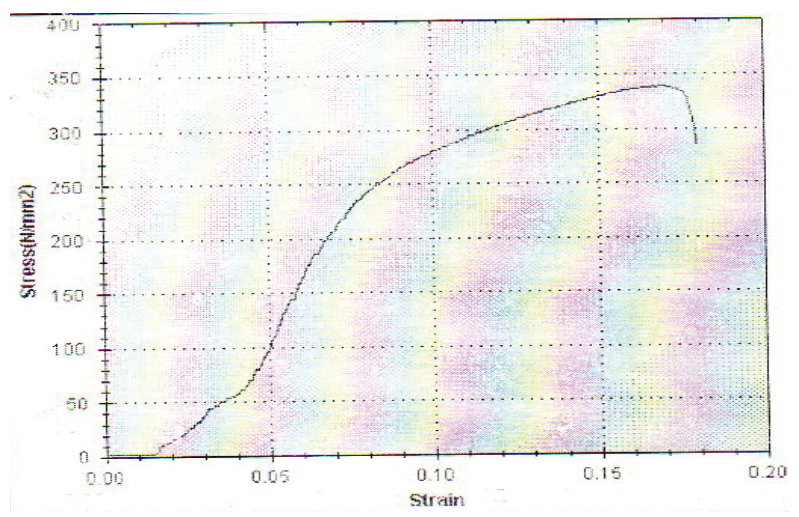

Fig.1 Stress Vs. Strain curve for sample-1

\begin{tabular}{|cc|}
\hline \multicolumn{2}{|c|}{ OUTPUT } \\
\hline Load at yield & $24.39 \mathrm{KN}$ \\
\hline Yield stress & $257.183 \mathrm{~N} / \mathrm{mm}^{2}$ \\
\hline Load at peak & $32.040 \mathrm{KN}$ \\
\hline Tensile strength & $337.849 \mathrm{~N} / \mathrm{mm}^{2}$ \\
\hline \% Elongation & $9.44 \%$ \\
\hline
\end{tabular}

Tab.5 Tensile test results of specimen-1 


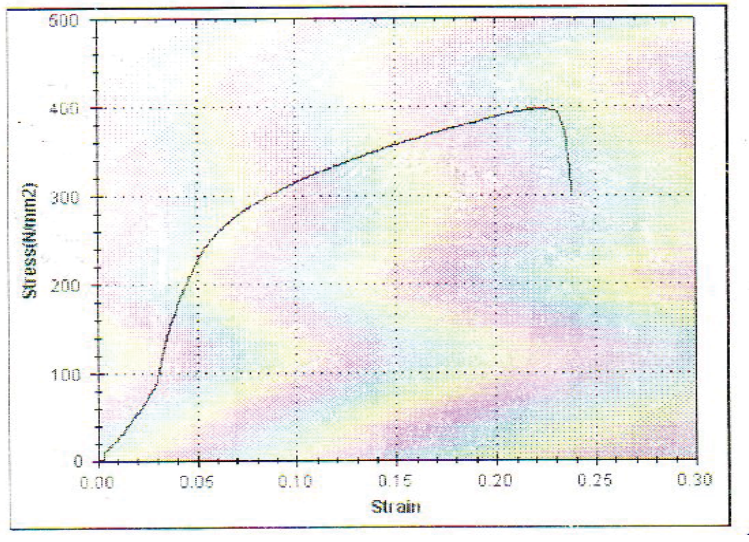

Fig.2 Stress Vs. Strain curve for sample-

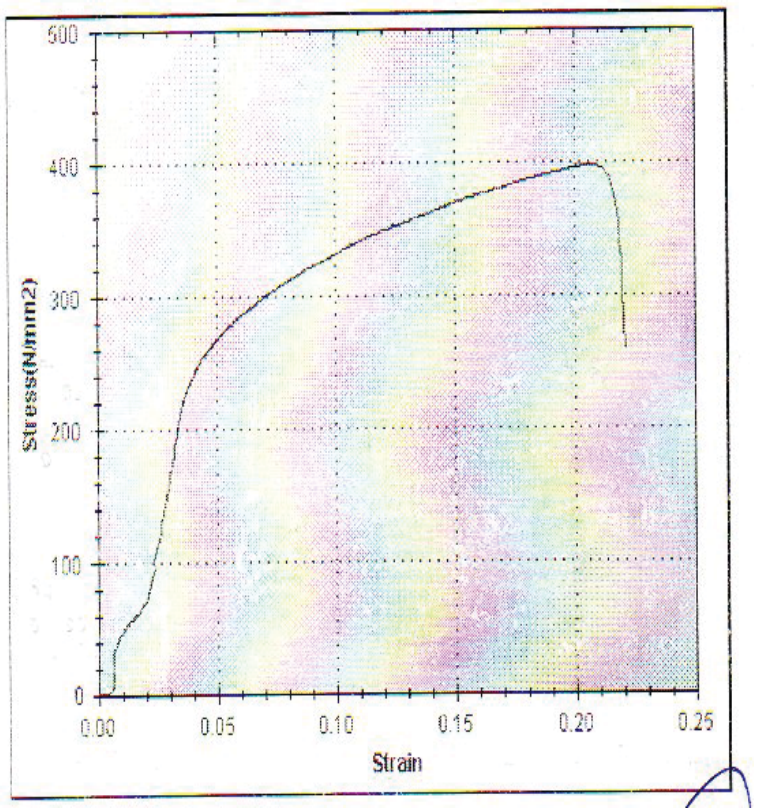

Fig.3 Stress Vs. Strain curve for sample-3

\begin{tabular}{|cc|}
\hline \multicolumn{2}{|c|}{ OUTPUT } \\
\hline Load at yield & $22.92 \mathrm{KN}$ \\
\hline Yield stress & $242.443 \mathrm{~N} / \mathrm{mm}^{2}$ \\
\hline Load at peak & $37.530 \mathrm{KN}$ \\
\hline Tensile strength & $396.985 \mathrm{~N} / \mathrm{mm}^{2}$ \\
\hline$\%$ Elongation & 14.74 \\
\hline
\end{tabular}

Tab.6 Tensile test results of specimen-2

\begin{tabular}{|cc|}
\hline \multicolumn{2}{|c|}{ OUTPUT } \\
\hline Load at yield & $24.12 \mathrm{KN}$ \\
\hline Yield stress & $254.223 \mathrm{~N} / \mathrm{mm}^{2}$ \\
\hline Load at peak & $37.740 \mathrm{KN}$ \\
\hline Tensile strength & \\
\hline & \\
\hline \% Elongation & \\
\hline
\end{tabular}

Tab.7 Tensile test results specimen-3 


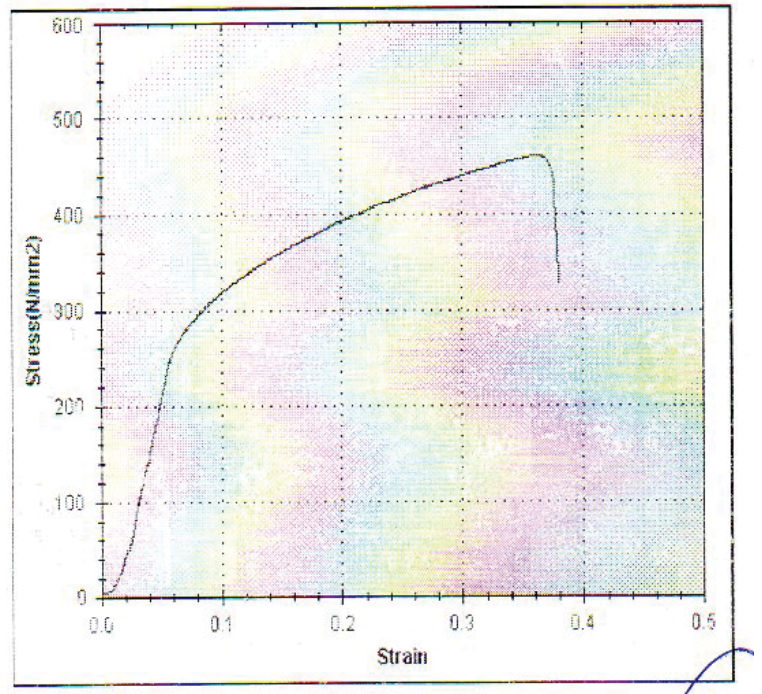

Fig.4 Stress Vs. Strain curve for sample-4

\begin{tabular}{|cc|}
\hline \multicolumn{2}{|c|}{ OUTPUT } \\
\hline Load at yield & $24.51 \mathrm{KN}$ \\
\hline Yield stress & $258.356 \mathrm{~N} / \mathrm{mm}^{2}$ \\
\hline & \\
\hline Load at peak & $43.560 \mathrm{KN}$ \\
\hline Tensile strength & $459.159 \mathrm{~N} / \mathrm{mm}^{2}$ \\
\hline \% Elongation & \\
\hline
\end{tabular}

Tab. 8 Tensile test results of specimen-4

\section{VICKERS HARDNESS}

The below are the Vickers hardness test results that are obtained for the four specimens on weld or fusion zone:

\begin{tabular}{|ccccc|}
\hline $\begin{array}{c}\text { Sample. } \\
\text { No }\end{array}$ & \multicolumn{2}{c}{ Hardness value } & $\begin{array}{c}\text { Average hardness } \\
\text { (HV 0.5) }\end{array}$ \\
\hline 1 & 189.2 & 193.1 & 182.9 & 188.4 \\
\hline 2 & 191.4 & 179.9 & 182.9 & 184.7 \\
\hline 3 & 185.5 & 183.9 & 180.4 & 183.2 \\
\hline 4 & 185.7 & 185.0 & 183.9 & 184.8 \\
\hline
\end{tabular}

V. MICROSTRUCTURE

The below are the micro structure results that are obtained for the four specimens:

Sample.1-

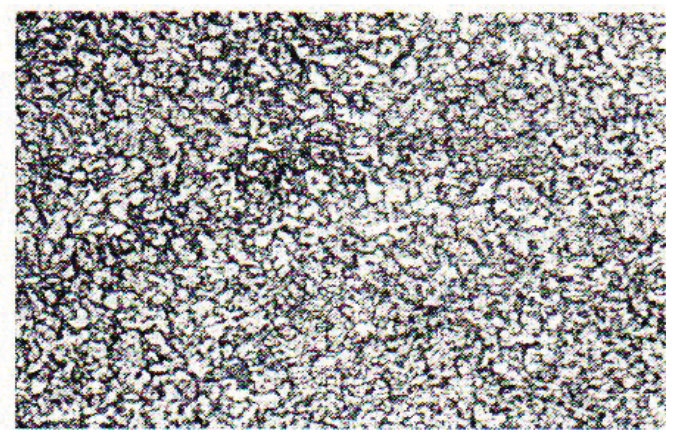

Fig.5 Micro structure at weld (or) fusion zone 
Micro structure consists of fine grains of inter-metallic particles. Non-uniform grains flow pattern are seen. No cracks and blow holes are observed.

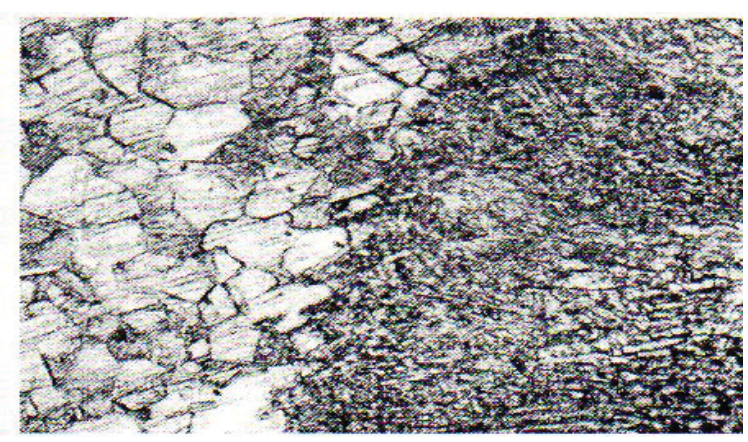

Fig.6 Micro structure at heat affected zone

Heat affected zone shows uniformly distributed of grains in a matrix of stainless steel solid solution. No cracks observed in heat affected zone.

Sample.2-

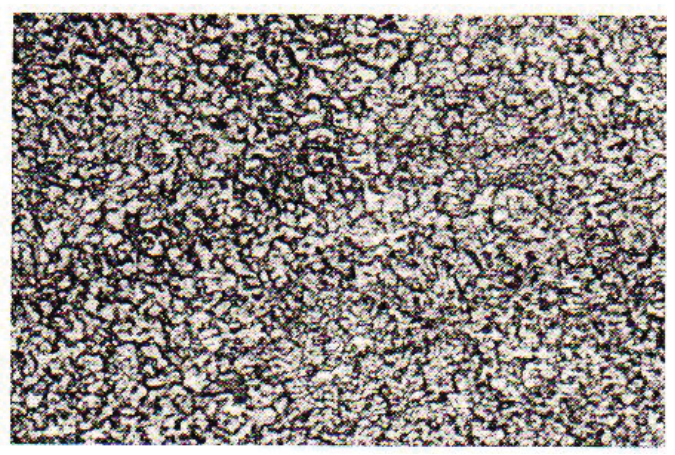

Fig.7 Micro structure at weld (or) fusion zone

Micro structure consists of fine grains of inter-metallic particles. Non-uniform grains flow pattern are seen. No cracks and blow holes are observed.

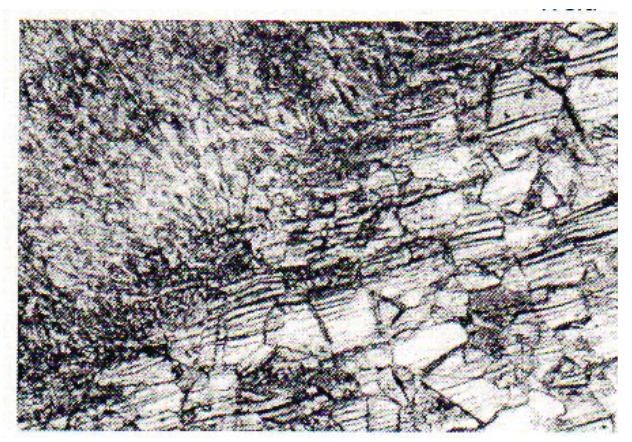


Fig.8 Micro structure at heat affected zone

Heat affected zone shows uniformly distributed of grains in a matrix of stainless steel solid solution. No cracks observed in heat affected zone.

\section{Sample.3-}

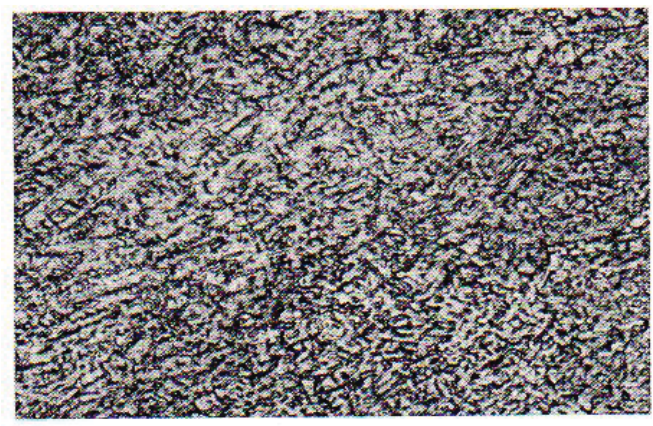

Fig.9 Micro structure at weld (or) fusion zone

Micro structure consists of fine grains of inter-metallic particles. Non-uniform grains flow pattern are seen. No cracks and blow holes are observed.

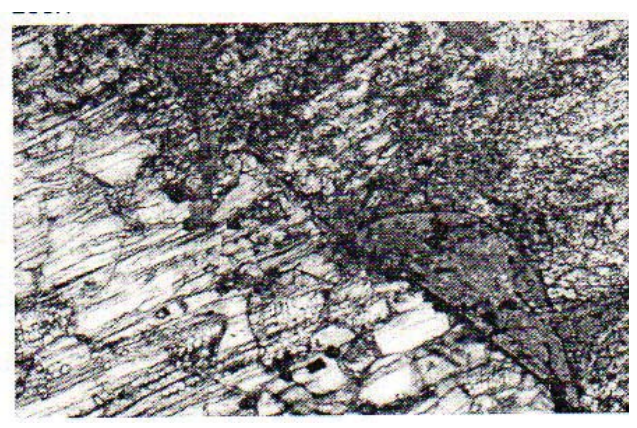

Fig. 10 Micro structure at heat affected zone

Heat affected zone shows non-uniformly distributed of grains in a matrix of stainless steel solid solution. Cracks observed in heat affected zone.

Sample.s4-

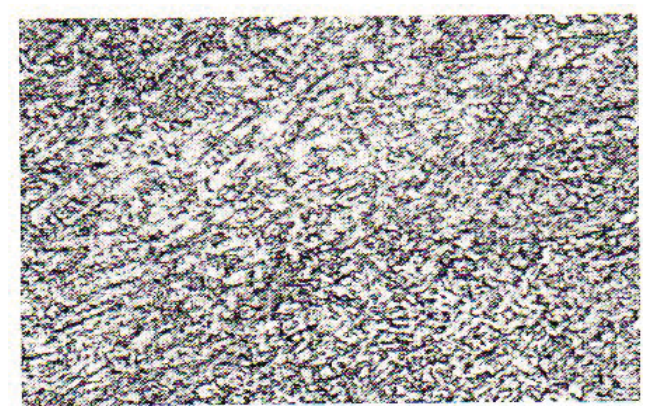

Fig.11 Micro structure at weld (or) fusion zone 
Micro structure consists of fine grains of inter-metallic particles. Non-uniform grains flow pattern are seen. No cracks and blow holes are observed.

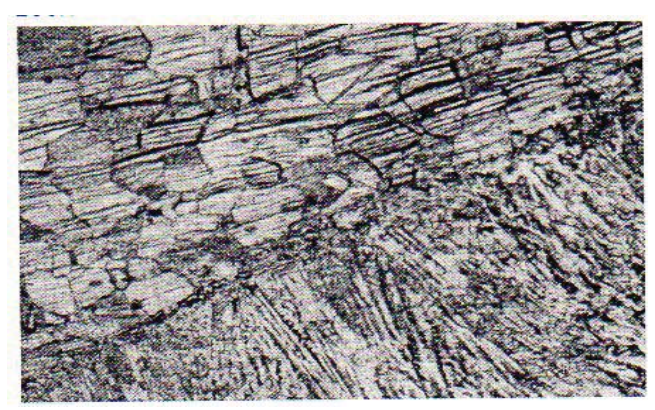

Fig.12 Micro structure at heat affected zone

Heat affected zone shows uniformly distributed of grains in a matrix of stainless steel solid solution. No cracks observed in heat affected zone.

\section{CONCLUSION}

From the results of the experimentation conducted on the four specimens of SS316 material it s found that the fourth specimen giving the highest tensile stress of $459.159 \mathrm{KN} / \mathrm{mm}^{2}$ and least tensile stress of $337.849 \mathrm{KN} / \mathrm{mm}^{2}$ for the first specimen, so it can be concluded that highest tensile stress with fine and uniformly distributed grains in the fusion and heat effected zone can be achieved by using $90 \mathrm{~A}, 1 \mathrm{~mm}$ as root gap with a little difference in the hardness value compared with the $\mathrm{VH}$ value of the first specimen.

\section{REFERENCES}

[1] Gadewar et. al. P. "Experimental investigations of weld characteristics for a single pass TIG welding with ss316L". / International Journal of Engineering Science and Technology Vol. 2(8), 2010, 3676-3686

[2] International Journal of Engineering Science and Technology (IJEST),ISSN : 0975-5462 Vol. 4 No.05 May 2012,C. BALAJI1 mechbalajisjce@yahoo.in S.V. ABINESH KUMAR2 abinesh.071890@gmail.com S. ASHWIN KUMAR3 "EVALUATION OF MECHANICAL PROPERTIES OF SS 316 L WELDMENTS USING TUNGSTEN INERT GAS WELDING "

[3] Er.Parvinder Singh, Er.Vikram Singh "Experimental investigation of weld bead hardness of TIG welding of grade ss316". Global journal of engineering science and researches, issn 2348 - 8034, may-2014.

[4] Optimization of 316 Stainless Steel Weld Joint Characteristics using Taguchi Technique P. Bharatha,V.G. Sridharb, M. Senthil kumarb, 12th GLOBAL CONGRESS ON MANUFACTURING AND MANAGEMENT, GCMM 2014, 1877-7058 @ 2014 Published by Elsevier Ltd,P. Bharath et al. / Procedia Engineering 97 ( 2014 ) 881 - 891This is an open access article under the CC BY-NC-ND license (http://creativecommons.org/licenses/by-nc-nd/3.0/).

[5] "Welding fundamentals" by Dr. R.S.Parmar. 